\title{
LIFE CYCLE OF MISUMENOPS PALLIDA (ARANEAE, THOMISIDAE)
}

\author{
ELISABET MINERVINO
}

Centro de Estudios Parasitológicos y de Vectores (CEPAVE), Calle $2 \mathrm{~N}^{\circ}$ 584, La Plata ( 1900 ), Buenos Aires, Argentina

Postembryonic development of Misumenops pallida (Keyserling) (Araneae, Thomisidae), one of the most abundant predator species in soybean fields in Buenos Aires Province (Argentina) was studied. The life cycle was observed in the laboratory from egg sacs collected in the field, and from egg sacs spined in the laboratory by gravid females collected in the field. Results indicated that instar length and feeding rate increased throughout the life cycle being higher in females than in males. Greater mortality was observed to third and fourth instars decreasing thereafter. These results may contribute to determine the efficiency of this species as a natural enemy of insect pests of soybean.

Key words: arthropods - spiders - postembryonic development - behavior - soybean

Soybean is one of the most important crop in Argentina. It is cultivated from NovemberDecember to April-May, and occupies an extensive area including center and west of Buenos Aires Province, and south of Santa Fe and Cordoba Provinces (Remussi \& Pascale, 1977).

Mayor pest species include the bud borer Epinotia aporema Wallsingham (Lepidoptera: Tortricidae), the defoliators Rachiplusia $n u$ (Gueneé) and Anticarsia gemmatalis Hübner (Lepidoptera: Noctuidae), and the pod-eating Piezodorus guildinii Westwood and Nezara viridula (L.) (Heteroptera: Pentatomidae) (Samuel, 1975).

Misumenops pallida (Keyserling) is one of the most abundant spider species in soybean fields in Buenos Aires Province, being a natural enemy of the above mentioned pests (Minervino, unpublished data).

Postembrionic development, mortality, feeding rates, instar duration, survivorship and life expectancy of $M$. pallida was studied.

\section{METHODS}

Observations were made from egg sacs collected in the field, and cgg sacs obtained in

Fellowship of Comision de Investigaciones Científicas de la Provincia de Buenos Aires.

Received 3 July 1992.

Accepted 28 December 1992. the laboratory by gravid females collected in the field. Egg sacs were collected from 40 soybean plants examined in the laboratory. Individuals were collected using a sweep-net $(50 \mathrm{~cm}$ of diameter), and picking by hand. Weekly samples were taken between January and March 1990 on a plot of 1 ha in size in La Plata district $\left(35^{\circ} \mathrm{S}, 58^{\circ} \mathrm{O}\right.$ ) (Buenos Aires Province).

From seven egg sacs obtained, four were opened for egg separation. Eggs were counted and postembryonic development observed. The remaining egg sacs were kept with their mothers to know the time between egg eclosion and the exit from egg sacs, and to check for possible maternal care.

The spiderlings borned in the laboratory were reared individually, at constant conditions $\left(23^{\circ} \mathrm{C}\right.$; LD $\left.14-10\right)$. Each individual was placed in a plastic jar $(3.5 \mathrm{~cm} \times 7.0 \mathrm{~cm})$. A piece of paper (for building the shelter) and a piece of moisture cotton (for mantaining humidity) were placed inside jars which were plugged with voyle, fixed with a elastic band. Individuals were fed each two days with adult flies of Drosophila melanogaster Meiger born in captivity. Daily observations were made from egg to third instar and every two days from the fourth instar on.

After each molt exuviae were kept in a dry recipient, in order to take instar ineasures using stereo microscope with an ocular micrometer. Description of instars was done based on Galiano $(1972,1991)$ nomenclature. 
Survivorship (lx) was calculated as:

$$
1 \mathrm{x}=\frac{\mathrm{Nx}}{\mathrm{No}}
$$

where: $\mathrm{Nx}=$ number of individuals which were alive in each stage; and No = total number of eggs which have hatched.

Life expectancy (ex) was calculated using:

$$
\mathrm{ex}=\frac{\mathrm{Tx}}{\mathrm{lx}}
$$

where: $T x=$ total number of remainder days in the life of an individual that had reached a $x$ age:

$$
\mathrm{Tx}=\sum_{\mathrm{m}}^{\mathrm{x}} \mathrm{lx}
$$

being $\mathrm{m}$ the maximun age which was reached.

\section{RESULTS AND DISCUSSION}

Egg sacs are white, oval shape $(7 \times 3 \mathrm{~mm})$, and have a silky appearance. They are covered with a thiny layer of soft threads. In the field, egg sacs were found during the last phenological stages of soybean (R6 and R7 acording to Fehr and Caviness, 1977), between the end of February to March, previous to harvest of this crop. The mean duration of life cycle of this species is 277 days (Table III), indicating that $M$. pallida spends part of its life cycle when soybean is not available in the field. Generally egg sacs were found in the back side of leaves or inside "shelthers" built by folding leaves and by sealing their edges with silk. These "shelters" covered with silk threads in the inner side, were used by females as refuges.

In the laboratory, females showed resistance to be separated from isolated egg sacs. When they were together, females stayed close to them continuously, even after egg eclosion. Females did not show aggressive behavior with the hatch, and usually did not feed.

Two out of four egg sacs observed were built by the same female in fourty days interval. The number of eggs per sac decreased with time, being 86 in the first and 37 in the second. Eggs are white, spheric with $1 \mathrm{~mm}$ diameter, gelatinous, and are difficult to separate to be counted.

Total number of eggs per sac was variable, with a range of 25-94 and mean of 60 . The total number of eggs of all sacs was 242 , being $60 \%$ of these (145) fertile (Table I).

TABLE I

Number of hatched and fertile eggs from each egg sacs of Misumenops pallida

\begin{tabular}{lccccccc}
\hline \multirow{2}{*}{ Number of eggs } & \multicolumn{6}{c}{ Egg sac number } \\
\cline { 2 - 8 } & 1 & 2 & 3 & 4 & Total & $\bar{X}$ & S.D. \\
\hline Hatched & 94 & 25 & 86 & 37 & 242 & 60,5 & 34,5 \\
Fertile & 56 & 15 & 52 & 22 & 145 & $\$ 6,2$ & 20,7 \\
\hline
\end{tabular}

First three instars developed inside the egg sac with the first instar being intrachorionic. Fourth instars developed outside the egg sac. During the third instar, the setae of the following instar could be observed, and individuals acquired more mobility. After 2-3 days, the third molt occurred, setae appeared, and eyes became pigmented. Individuals started making web and were able to catch prey. During this stage they abandon the egg sac and start dispersing. These observations are similar to those reported to other species of spiders of the genus Misumenops (Shick, 1972).

An increase in average duration of instars as spiders progressed in their development was observed except in the eighth instar (previous to adult) (Table II). Four males and only one female were obtained from all the eggs observed, which prevented calculation of mean and standard desviation values for adult females. Females collected in the field as preadults and reared in the laboratory to reach adulthood, had an average duration of immature cycle of $161.3 \pm 45.4$ days, and range 128-213 days (Table II).

The mean life span (from eclosion to death) was 277 days and the mean duration of adult life 97 days (Table III).

Females reached maturity after seven molts and $50 \%$ of males reached maturity after six molts. The remaining $50 \%$ reached maturity after seven molts. This difference may be explained because females were always larger than males (Table IV), as a consequence they usually need one more molt to reach maturity. 


\section{TABLE II}

Average duration (days) ( $\overline{\mathrm{X}} \pm$ s.d.) and range, of each instar in the life cycle of Misumenops pallida.

$\mathrm{N}=$ number of individuals, $q$ adult $(\mathrm{L})=$ female from egg sacs reared in the laboratory, $q$ adult $(F)=$ females collected in the field as preadults

\begin{tabular}{lrrr}
\hline $\begin{array}{l}\text { Stage of } \\
\text { development }\end{array}$ & $\mathrm{N}$ & $(\overline{\mathrm{X}} \pm$ s.d. $)$ & Range \\
\hline Instar 3 & 145 & $2,5 \pm 0,51$ & $2-3$ \\
Instar 4 & 135 & $15,0 \pm 6,45$ & $1-34$ \\
Instar 5 & 14 & $12,2 \pm \pm 5,87$ & $6-24$ \\
Instar 6 & 7 & $22,0 \pm 11,88$ & $4-34$ \\
Instar 7 & 6 & $65,0 \pm 17,44$ & $13-176$ \\
Instar 8 & 5 & $33,66 \pm 28,00$ & $17-66$ \\
Oadult & 4 & $69,2 \pm 30,76$ & $33-119$ \\
Qdadult (L) & 1 & 143,0 & \\
Oadult (F) & 10 & $161,3 \pm 45,4$ & $128-213$ \\
\hline
\end{tabular}

TABLE III

Duration (days) ( $\overline{\mathrm{X}}$, range and standard desviation (S.D.)) of life cycle of Misumenops pallida

\begin{tabular}{lrrr}
\hline Life cycle phases & $\overline{\mathrm{X}}$ & Range & S.D. \\
\hline Eclosion-last molt & 151 & $71-253$ & 51,7 \\
Dispersion-last molt & 148 & $69-250$ & 49,8 \\
Eclosion-death & 277 & $367-226$ & 43,8 \\
Last molt-death & 97 & $31-214$ & 43,2 \\
\hline
\end{tabular}

Food consumed increased throughout life cycle reaching the maximum for females (Table $V$ ). This could be explained because of females bigger size and because they need to store major amounts of nutrients for reproduction.

Mortality affected mainly third and fourth instars, at the time of dispersion of the spiderlings. From this stage on they must start making the web and to hunt their preys. These events constitute a critic situation which increases mortality. In the next instar (fifth) mortality starts to decrease reaching zero in the final instar, when survivorship stabilizes (Fig.). This curve resembles the type IV survivorship curve from Slobodkin (1962).

\section{TABLE V}

Feeding rates (number of flies/spider/day) of Misumenops pallida ( $\overline{\mathrm{X}} \pm$ S.D. and range). Mean values followed by the same letter are not significantly different $(\mathrm{P}>0,05)$ by Student test (Sokal y Rohlf, 1979)

\begin{tabular}{lcc}
\hline & \multicolumn{2}{c}{ Flies/spider/day } \\
Stage of development & $\overline{\mathrm{X}} \pm$ S.D. & Range \\
\hline Instar 4 & $0,36 \pm 0,01 \mathrm{a}$ & $0,51-0,22$ \\
Instar 5 & $0,43 \pm 0,08 \mathrm{a}$ & $0,70-0,35$ \\
Instar 6 & $0,68 \pm 0,17 \mathrm{a}$ & $0,82-0,40$ \\
Instar 7 & $0,74 \pm 0,20 \mathrm{a}$ & $1,03-0,44$ \\
Instar 8 & $1,75 \pm 1,12 \mathrm{~b}$ & $2,22-1,09$ \\
ठAd & $1,03 \pm 0,29 \mathrm{c}$ & $0,78-1,15$ \\
OAd & $3,50 \pm 1,87 \mathrm{~d}$ & $0,50-6,21$ \\
\hline
\end{tabular}

Life expectancy (Fig.) presents one peaks at fourth and at fifth instars, these being critic ages of this species because of greater mortality risk. From the sixth instar on this curve decreases progressively as advance in age occurrs (Deevey, 1947; Rabinovich, 1980).

Adult phase occupies $1 / 3$ of the entire life cycle duration and presents the higher values to instar length, size and feeding rate, and the lower values of mortality. Therefore the adult stage is very important in the development of M. pallida.

\section{TABLE IV}

Measures of: total length, cephalotorax (length and width) and abdomen (length and width) for each instar (in mm) $(\overline{\mathrm{X}} \pm$ S.D. and range)

\begin{tabular}{|c|c|c|c|c|c|c|c|c|c|c|}
\hline \multirow{3}{*}{$\begin{array}{l}\text { Stage of } \\
\text { development }\end{array}$} & \multirow{2}{*}{\multicolumn{2}{|c|}{ Total length }} & \multicolumn{4}{|c|}{ Cephalotorax } & \multicolumn{4}{|c|}{ Abdomen } \\
\hline & & & \multicolumn{2}{|c|}{ Length } & \multicolumn{2}{|c|}{ Width } & \multicolumn{2}{|c|}{ Length } & \multicolumn{2}{|c|}{ Width } \\
\hline & $\overline{\mathrm{X}} \pm$ S.D. & Range & $\overline{\mathrm{X}} \pm$ S.D. & Range & $\overline{\mathrm{X}} \pm$ S.D. & Range & $\bar{X} \pm$ S.D. & Range & $\bar{X} \pm S . D$ & Range \\
\hline Instar 3 & $3,2 \pm 0,35$ & $2,9-3,6$ & $1,8 \pm 0,15$ & $1,5-2,0$ & $1,6 \pm 0,12$ & $1,3-1,8$ & $1,8 \pm 0,17$ & $1,6-2,1$ & $1,6 \pm 0,09$ & $1,4-1,7$ \\
\hline Instar 4 & $5,0 \pm 1,22$ & $4,1-6,3$ & $2,0 \pm 0,19$ & $1,8-2,5$ & $1,6 \pm 0,11$ & $1,5-2,0$ & $3,0 \pm 0,21$ & $2,5-3,0$ & $1.6 \pm 0,08$ & $1,5-1,8$ \\
\hline Instar 5 & $5,4 \pm 1,45$ & $4,1-6,8$ & $2,6 \pm 0,26$ & $2,0-3,0$ & $2,4 \pm 0,37$ & $2,0-3,0$ & $3,0 \pm 0,33$ & $2,5-3,5$ & $2,0 \pm 0,42$ & $1,5-2,5$ \\
\hline Instar 6 & $6,0 \pm 2,78$ & $4,0-7,5$ & $3,0 \pm 0,37$ & $2,3-4,0$ & $3,0 \pm 0,36$ & $2,6-3,5$ & $3,0 \pm 0,29$ & $2,8-4,2$ & $2,0 \pm 0,35$ & $1,8+3,2$ \\
\hline Instar 7 & $8,0 \pm 2,93$ & $5,0-10$ & $4,0 \pm 0,50$ & $3,0-5,0$ & $3,6 \pm 0,41$ & $3,0-4,0$ & $4,0 \pm 0,39$ & $3,5-4,5$ & $3,0 \pm 0,40$ & $2,5-2,5$ \\
\hline Instar 8 & $8,4 \pm 2,90$ & $5,5-10,5$ & $4,0 \pm 0,52$ & $3,7-5,2$ & $3,8 \pm 0,40$ & $3,4-4,3$ & $4,4 \pm 0,44$ & $3,5-5,2$ & $4,0 \pm 0,50$ & $3,0-4,0$ \\
\hline$\partial \mathrm{Ad}$ & $9,0 \pm 3,05$ & $6,1-13,3$ & $4,0 \pm 0,49$ & $4,0-5,5$ & $4,2 \pm 0,42$ & $3,5-4,5$ & $5,0 \pm 0,53$ & $4,3-6,0$ & $4,0 \pm 0,52$ & $3,4-4,6$ \\
\hline \% Ad & $14,0 \pm 3,57$ & $9,0-16,0$ & $5,0 \pm 0,52$ & $4,5-6,0$ & $5,0 \pm 0,49$ & $4,7-5,0$ & $9,0 \pm 0,70$ & $8,5-9,5$ & $9,0 \pm 0,71$ & $10-15,0$ \\
\hline
\end{tabular}




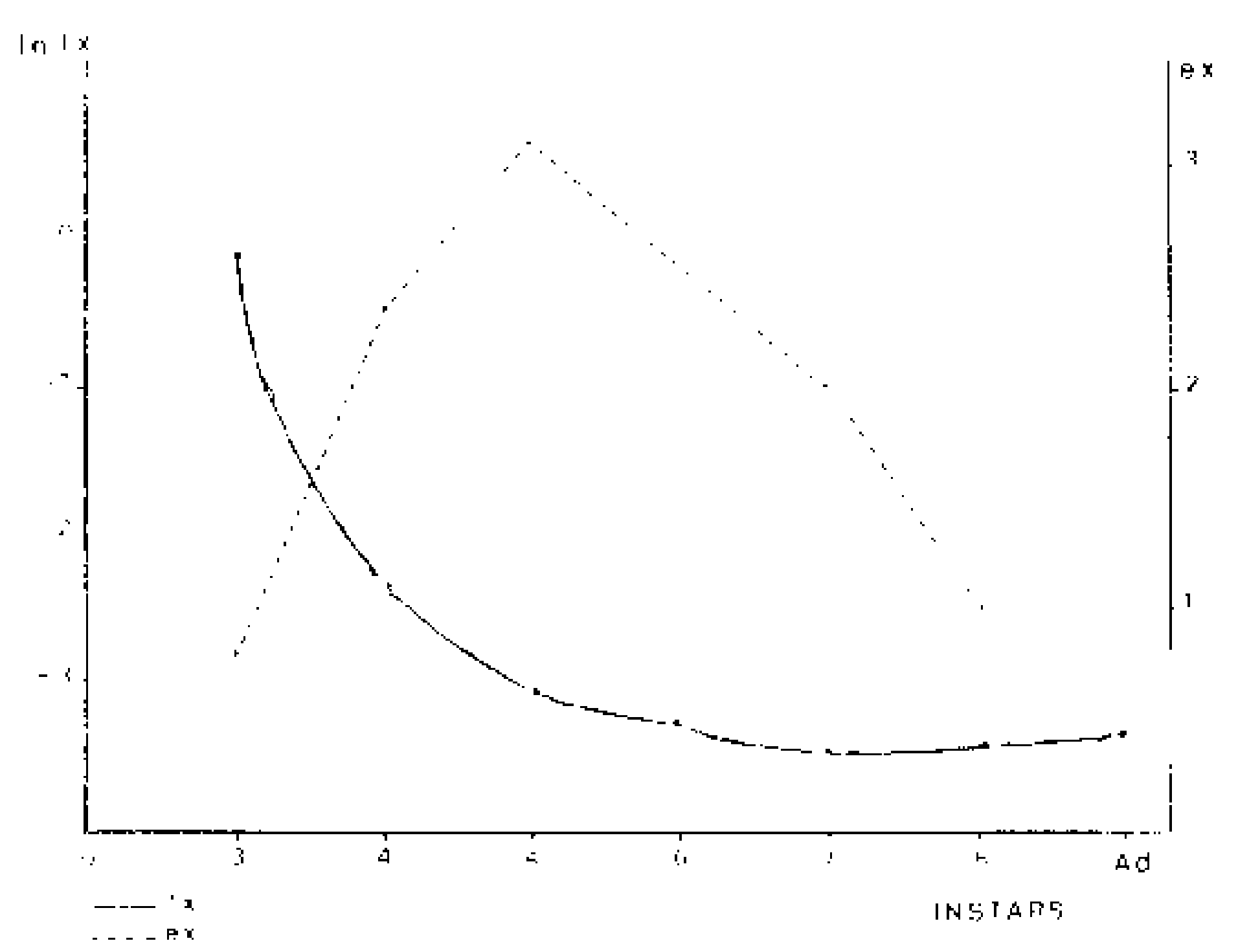

Survivorship (lx) and life expectancy (ex) of Misumenops pallida.

\section{ACKNOWLEDGEMENTS}

To Dr Gerardo Liljesthröm, Dr Norma Sanchez and Dr Patricia Pereyra from CEPAVE and Dr Alda Gonzalez from Facultad y Museo de Ciencias Naturales de La Plata for critically reviewing the manuscript. To $\mathrm{Dr}$ Arno Lise from Museu de Ciencias da Pucrs, Porto Alegre, Brasil, for identifying the spiders of the Thomisidae family, and to the staff of Cooperativa Agrícola y Ganadera de Chivilcoy S.A. (specially to Ing. Jorge Grisolía) for his disinterested collaboration through the provision of seeds, fungicide and others necessary elements in the sowing of experimental plots of soybean. To Dr Alda Gonzalez and to my brother Ricardo for technical assistance.

\section{REFERENCES}

DEEVEY, E., 1947. Life tables for natural population of animals. Quart. Rev. Biol., 22: 283-314.

FEHR. W. R. \& C. E. CAVINESS, 1977. Stages of soybean development. Iowa Coop. Ext. Serv. Specc. Rep. $80: 12$ p.

GALIANO, M. E., 1972. El desarrollo postembrionario larval de Ischnothele siemensi Cambridge, 1896 (Araneac, Dipluridae). Physis, Bs. As, 31: 169-177.

GALIANO, M. E., 1991. Postembryonic development in ten spccies of neotropical Salticidac (Araneae). Bull. Br. Arachnol. Soc., 8: 209.218.

RABINOVICH, J., 1980. Introducción a la ecologia de las poblaciones animales. Cia. Editorial Continental, Mexico.

REMUSSI, C. \& A. PASCALE, 1977. La soja. Cultivo, mejoramiento, comercialización, usos. Enciclopedia Argentina de Agricultura y Ganadería. Tomo II, Fasciculo 12-14.

SAMUEL, H., 1975. Soja: Información técnica para su mejor conocimiento y cultivo. Ed. Hemisferio Sur, Buenos Aires.

SCHICK, R, 1972. The early instars, larval feeding and the significance of larval feeding in the crab spider genus Misumenops (Araneae: Thomisidae). Notes of Arachnologists of the Southwest. Number 3.

SLOBODKIN, L., 1962. Growth and regulation of animal populations. Holt, Rinehart \& Winston. New York.

SOKAL, R. \& ROHLF, F. J., 1979. Biometria. Principios y métodos estadísticos en la investigación cientifica. 1 ra. ed. H. Blume Ediciones, Madrid, xi +832 p. 